\title{
STUDIES ON WATER-DRINKING
}

\author{
IV. TIIE EXCRETION OF CHLORIDS FOLLOWING COPIOUS WATER-DRINKING \\ BETWEEN MEALS * 1
}

\author{
S. A. RULON, JR., M.D., ANd P. B. HAWK, Ph.D. \\ ERBANA, ILL.
}

Considerable investigating has been done on the influence of copious water ingestion on the chlorid excretion of fasting animals. The work of Forster $^{2}$ is often quoted in this connection. In one instance this investigator increased the urinary chlorid output from $0.175 \mathrm{gm}$. to $0.992 \mathrm{gm}$. by causing a dog to ingest 3 liters of water on the eighth day of the fast. This is the most pronounced increase in the chlorid excretion yet reported as following the ingestion of large volumes of water. From a series of investigations on dogs in which different animals were subjected to the influence of external hemorrhage or to the influence of poisoning by phosphorus or by carbon monoxid Kast ${ }^{3}$ later came to the conclusion that there was a very close relationship between increased protein catabolism and the augmented chlorin output accompanying such catabolism. Inasmuch as the procedure of Kast rendered his experimental animals abnormal the results obtained therefrom cannot be considered on a comparative basis with the data obtained from a study of the course of the metabolic processes of normal subjects. Heilner ${ }^{4}$ in a more recent study of copious water-drinking failed to secure any uniform relationship between the increased catabolism of protein matter, as measured by the increased output of nitrogen, and the accompanying rise in the chlorid excretion. In one experiment the ratio of chlorin to nitrogen was $1: 16 . \%$, whereas in a second test the ratio was $1: 6.9$. Benedict $\dagger$ has also found that the intensity of protein catabolism cannot be correctly judged from a consideration of the chlorin output.

\section{REPORT OF EXPERIMENTS}

\section{EXPERIMENT $\mathbf{Y}$}

The purpose of this investigation was the study of the influence on the chlorid excretion of large amounts of water taken between meals. The subject of the

* From the laboratories of physiological chemistry of the University of Illinois and of the department of medicine of the University of Pennsylvania.

1. For I, II and III of this series of studies see, respectively: Hawk: Univ. Penn. Med. Bull., 1905, xviii, 7; Fowler and Hawk: Jour. Exper. Med., 1910, xii, 388; Rulon and Hawk: Jour. Am. Chem. Soc., 1910, xxxii, 1686.

2. Forster: Ztschr. f. Biol., 1873, ix, 364.

3. Kast: Ztschr. f. physiol. Chem., 1888, xii, 267.

4. Heilner: Ztschr. f. Biol., 1906, xlvii, 538.

$\dagger$ Benedict: Carnegie Publication, No. 77. 
experiment was a young man 24 years of age who was a third-year student of medicine. His body weight was $60.6 \mathrm{~kg}$. The plan adopted was to place the subject on a uniform diet containing a moderate amount of water and to continue this diet until nitrogen equilibrium was attained. After the course of the normal nutrition of the equilibrium plane had been noted it was then proposed to cause the subject to ingest a large volume of water through a period of four days and to note the influence of this increased ingestion of fluid on the urinary concentration of chlorids. Following this water period it was proposed to place the subject again on the original diet fed at the time nitrogen equilibrium was being attained in order to observe any metabolic variations which should follow the copious ingestion of water. The three periods of the experiment, i. e., the preliminary, water and final periods, were three, four and two days in length respectively.

The meals were taken at 7:30 a. m., 12:30 p. m. and 5:30 p. m., the menu for each meal being $700 \mathrm{gm}$. of whole milk, $40 \mathrm{gm}$. of butter and $100 \mathrm{gm}$. of soda crackers. During the entire experiment 100 c.c. of water was taken with each meal. This water ingestion was supplemented during the preliminary and final periods by the ingestion of 100 c.c. additional at $10 \mathrm{p.} \mathrm{m}$. During the water period, however, 400 c.c. of water was taken hourly from $8 \mathrm{a}$. m. to $9 \mathrm{p}$. m. and 300 c.c. at 10 p. m. Moderate exercise of a uniform character was taken by the subject each day.

The body weight was accurately determined each day before breakfast and immediately following the emptying of bladder and rectum. The urine was collected in twenty-four-hour samples during the first two days of the preliminary period and the last day of the final period. During each of the other days of the investigation the urine was collected in four three and one-half-hour periods beginning at $8 \mathrm{a} . \mathrm{m}$. and in a fifth period ten hours in length beginning at 10 p. m. Powdered thymol was used as urine preservative. The method of Volhard was used in the quantitative determination of the chlorids.

Discussion of Data from Experiment I.-The data obtained in the quantitative determination of urinary chlorids in this experiment are given in Table 1. It will be observed that the excretion of chlorids for the first day of the preliminary period was equivalent to $10.66 \mathrm{gm}$. of sodium chlorid, this value being increased to $11.04 \mathrm{gm}$. and $10.90 \mathrm{gm}$. on the other days of the period. The average output of chlorids by way of the urine for this preliminary period was equivalent therefore to 10.87 gm. of sodium chlorid. On the first day of the water period, however, when the ingestion of water was increased from 400 c.c. per day to 5,900 c.c., the chlorid outgo was slightly increased. The excretion for this day aggregated $11.49 \mathrm{gm}$. expressed as sodium chlorid. The day following, however, that is, the second day of increased fluid intake, the urinary concentration of chlorids decreased somewhat from the value observed on the first day of the period and very nearly approached the average value for the preliminary period. In fact, this value for the day in question was practically identical with the average value for the last two days of the preliminary period. The excretions in question were an average of $10.97 \mathrm{gm}$. for the last two days of the preliminary period as against $10.96 \mathrm{gm}$. for the second day of the water period. Following this return to the normal plane the chlorids again increased on the third day of copious water ingestion, as is shown by an output of $11.33 \mathrm{gm}$. expressed as sodium chlorid. The excretion on the fourth and last day 
of this period $(11.19 \mathrm{gm}$.) was somewhat above the normal plane, but less than the previously mentioned excretions observed on the first and third days.

TABLE 1.-CHLORID EXCRETION-EXPERIMENT I

\begin{tabular}{|c|c|c|c|c|c|c|}
\hline \multirow[b]{2}{*}{ Period } & \multirow{2}{*}{ 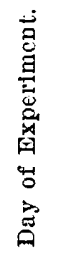 } & \multirow{2}{*}{ 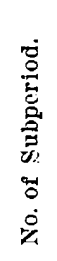 } & \multicolumn{2}{|c|}{$\begin{array}{l}\text { Urine } \mathrm{E} \\
\text { Volume }\end{array}$} & \multicolumn{2}{|c|}{$\begin{array}{l}\text { Examination } \\
\text { Chlorid Excretion }\end{array}$} \\
\hline & & & 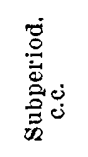 & 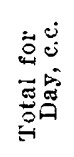 & 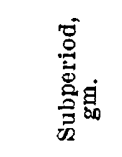 & 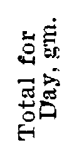 \\
\hline Preliminary ( 400 c.c. of water per day) $\cdot \frac{1}{2}$ & $\begin{array}{l}1 \\
2\end{array}$ & $\dot{.}$ & $\cdots$ & $\begin{array}{r}900 \\
1330\end{array}$ & $\cdots$ & $\begin{array}{l}10.66 \\
11.04\end{array}$ \\
\hline Preliminary ( 400 c.c. of water per day) ..3 & 3 & $\begin{array}{l}1 \\
2 \\
3 \\
4 \\
5\end{array}$ & $\begin{array}{l}140 \\
235 \\
260 \\
360 \\
355\end{array}$ & 1350 & $\begin{array}{l}1.82 \\
2.18 \\
3.00 \\
1.63 \\
2.27\end{array}$ & 10.90 \\
\hline Water (5900 c.c. of water per das) . . . 1 & 4 & $\begin{array}{l}1 \\
2 \\
3 \\
4 \\
5\end{array}$ & $\begin{array}{r}720 \\
1750 \\
1580 \\
1360 \\
1310\end{array}$ & 6720 & $\begin{array}{l}2.05 \\
2.63 \\
2.35 \\
1.84 \\
2.62\end{array}$ & 11.49 \\
\hline Water $(5900$ c.c. of water per day) $\ldots \ldots 2$ & $\tilde{5}$ & $\begin{array}{l}1 \\
2 \\
3 \\
4 \\
5\end{array}$ & $\begin{array}{r}680 \\
1750 \\
1400 \\
1320 \\
1170\end{array}$ & 6320 & $\begin{array}{l}1.60 \\
2.54 \\
2.17 \\
2.31 \\
2.34\end{array}$ & 10.96 \\
\hline Water ( 5900 c.e. of water per day) ....3 & 6 & $\begin{array}{l}\mathbf{1} \\
\mathbf{2} \\
\mathbf{3} \\
\mathbf{4} \\
\mathbf{5}\end{array}$ & $\begin{array}{r}730 \\
1670 \\
1200 \\
1380 \\
1530\end{array}$ & 6.530 & $\begin{array}{l}1.64 \\
2.39 \\
1.92 \\
2.28 \\
3.10\end{array}$ & 11.33 \\
\hline Water (5900 c.c. of water per day) $\ldots \ldots 4$ & 7 & $\begin{array}{l}1 \\
2 \\
3 \\
4 \\
5\end{array}$ & $\begin{array}{r}620 \\
1800 \\
840 \\
1300 \\
970\end{array}$ & 5.530 & $\begin{array}{l}1.51 \\
2.52 \\
1.81 \\
1.95 \\
\mathbf{3 . 4 0}\end{array}$ & 11.19 \\
\hline Final ( 400 c.e. of water per day) $\ldots \ldots 1$ & 8 & $\begin{array}{l}1 \\
2 \\
3 \\
4 \\
5\end{array}$ & $\begin{array}{l}140 \\
185 \\
170 \\
215 \\
315\end{array}$ & 1025 & $\begin{array}{l}1.54 \\
2.32 \\
1.98 \\
2.76 \\
3.65\end{array}$ & 12.25 \\
\hline Final ( 400 c.c. of water per day) . . . .2 & 9 & . & .. & 790 & $\cdots$ & 9.80 \\
\hline
\end{tabular}

On the eighth day of the investigation the water ingested was reduced in volume to that taken during the preliminary period. An examination of Table 1 will indicate that the decreased fluid intake was not followed by a decreased chlorid output. In fact, it will be observed that the chlorid excretion for this day was not only higher than that for any day of the preliminary period, but moreover it exceeded by a comparatively wide margin that registered for any day of the water period. It is of considerable interest that an excretion of $12.25 \mathrm{gm}$. should be obtained on this day, when all the dietary factors were the same as those which obtained during the preliminary period, when the average excretion was but $10.97 \mathrm{gm}$. This excretion of $12.25 \mathrm{gm}$. embraced a larger increased output of chlorids than was secured during the entire four days of the 
water period. During the four days in question the chlorid output was increased $1.08 \mathrm{gm}$. above the normal, whereas the $12.25 \mathrm{gm}$. represents an increase of $1.28 \mathrm{gm}$. above the preliminary level. The increased excretion on this single day at the opening of the final period therefore exceeded the total increase of the entire water period by more than 18 per cent. This high value of $12.25 \mathrm{gm}$. was succeeded on the following day, the last of the experiment, by an output of $9.8 \mathrm{gm}$. of chlorids expressed as sodium chlorid.

\section{EXPERIMENT II}

The chlorid data discussed in this connection were obtained from the analysis of urines collected during an investigation already reported. ${ }^{5}$ The subject was a young man 29 years old possessing a body weight of $61.5 \mathrm{~kg}$. The daily schedule was similar to that in Experiment I except that the hours for meals were different, breakfast being at $9 \mathrm{a}$. m., luncheon at $1 \mathrm{p}$. m. and dinner at $6 \mathrm{p}$. m. The three uniform meals each included $25 \mathrm{gm}$. of butter, $110 \mathrm{gm}$. of erackers and 600 gm. of whole milk. The extra volume of water ingested during each day of increased water ingestion was 4,500 c.c., one liter being taken at 11 a. m., $12 \mathrm{~m}$., $3: 30 \mathrm{p} . \mathrm{m}$. and $8 \mathrm{p}$. m., and 500 c.c. at $10 \mathrm{p}$. m. This experiment was nine days in length, three days being devoted to the preliminary period, two days to the water period and four days to the final period.

TABLE 2-CHLORID EXCRETION-EXPERIMENT II

\begin{tabular}{|c|c|c|c|c|c|}
\hline \multirow[b]{2}{*}{ Period } & \multirow[b]{2}{*}{$\begin{array}{l}\text { Day } \\
\text { of } \\
\text { Period }\end{array}$} & \multirow[b]{2}{*}{$\begin{array}{l}\text { Day } \\
\text { of } \\
\text { Experiment }\end{array}$} & \\
\hline & & & $\begin{array}{l}\text { Volume } \\
\text { c.c. }\end{array}$ & $\begin{array}{l}\text { Specific } \\
\text { Gravity }\end{array}$ & $\begin{array}{l}\text { Chlorid } \\
\text { Content } \\
\text { gm. }\end{array}$ \\
\hline Preliminary (500 c.c. of water per day) & $\cdots\left\{\begin{array}{l}1 \\
2 \\
3\end{array}\right.$ & $\begin{array}{l}1 \\
2 \\
3\end{array}$ & $\begin{array}{r}1090 \\
997 \\
770\end{array}$ & $\begin{array}{l}1018 \\
1020 \\
1023\end{array}$ & $\begin{array}{l}7.90 \\
8.82 \\
7.23\end{array}$ \\
\hline Water $(5,000$ c.c. of water per day $) \ldots$ & $\cdots \frac{1}{2}$ & $\begin{array}{l}4 \\
5\end{array}$ & $\begin{array}{l}5250 \\
5800\end{array}$ & $\begin{array}{l}1005 \\
1005\end{array}$ & $\begin{array}{l}11.55 \\
10.44\end{array}$ \\
\hline Ninal ( 500 c.c. of water per day) .. & $\begin{array}{r}1 \\
2 \\
3 \\
4 \\
4\end{array}$ & $\begin{array}{l}6 \\
7 \\
8 \\
9\end{array}$ & $\begin{array}{r}1275 \\
1160 \\
1140 \\
885\end{array}$ & $\begin{array}{l}1016 \\
1018 \\
1020 \\
1024\end{array}$ & $\begin{array}{l}7.39 \\
8.23 \\
8.77 \\
7.34\end{array}$ \\
\hline
\end{tabular}

Discussion of Data from Experiment II.-During the preliminary period of three days 400 c.c. of water above that contained in the 1,800 c.c. of milk was daily ingested. On this diet the chlorid output was 7.9 gm., $8.82 \mathrm{gm}$. and $7.23 \mathrm{gm}$. respectively. The average output for this three-day period, therefore, was $7.98 \mathrm{gm}$. On the day of the increased water ingestion, i. e., when 4,500 c.c. of water above that normally taken was introduced into the body, the chlorid excretion increased to $\mathbf{1 1 . 5 5}$ gm. On the following day on a similar water ingestion the chlorid output aggregated $10.44 \mathrm{gm}$., a value far above the preliminary level but somewhat lower than that registered on the first day of the water period. The chlorid excretion for the four days of the final period ranged from $7.34 \mathrm{gm}$. to $8.7 \% \mathrm{gm}$., yielding an average daily output of $7.93 \mathrm{gm}$. This average output agrees very closely with that obtained for the preliminary period, i. e., $7.98 \mathrm{gm}$. The data for this experiment are given in Table 2.

5. Hawk: Loc. cit. These analyses were made by Dr. F. D. Crowl. 
EXPERIMENT III

The data here discussed were obtained from urines collected in an experiment on the cryoscopic characteristics of urine following copious water ingestion. ${ }^{\circ}$ The experiment was similar to Experiment II, already discussed. The experimental periods were divided as follows: preliminary, four days; water, three days; final, two days. The general plan of the experiment as well as the character and arrangement of the meals and the volume of extra water ingested each day of the water period were similar to those in Experiment II. The diet, however, contained about the same quantity of chlorid as the one fed in Experiment I. The subject of the experiment was a young man 22 years of age who was a thirdyear medical student.

TABLE 3.-CHIORID EXCEETION-EXPERIMENT III

Feriod

\begin{tabular}{|c|c|c|}
\hline & Day & --Urine Data \\
\hline $\begin{array}{l}\text { of } \\
\text { Period }\end{array}$ & $\begin{array}{c}\text { of } \\
\text { Experiment }\end{array}$ & $\begin{array}{l}\text { Chlorid } \\
\text { Content, c.c. }\end{array}$ \\
\hline
\end{tabular}

Preliminary (500 c.c. of water per day)... $\left\{\begin{array}{l}1 \\ 2 \\ 3 \\ 4\end{array}\right.$

$1 \quad 1500 \quad 16.43$

Water (5000 c.c. water per day) ....... \{ $\left\{\begin{array}{l}1 \\ 2 \\ 3\end{array}\right.$

Final (500 c.c. of water per day) ....... $\left\{\begin{array}{l}2 \\ 1\end{array}\right.$

$\begin{array}{rrr}2 . & 1300 & 11.71 \\ 3 & 900 & 10.88\end{array}$

$+\quad 900 \quad 11.48$

$\begin{array}{lll}\mathbf{5} & \mathbf{4 1 0 0} & \mathbf{1 5 . 5 8} \\ \mathbf{6} & \mathbf{5 5 . 5 0} & \mathbf{2 5 . 1 4}\end{array}$

$\begin{array}{lll}7 & 4370 & \mathbf{1 5 . 6 4}\end{array}$

$9 \quad 1150011.21$

Discussion of the Data from Experiment 111 .- The data concerned are given in Table 3 . The data there given indicate that the chlorid output for the first day of the experiment (16.43 gm.) was considerably influenced by the diet ingested previous to the experimental time. This value is therefore not taken into consideration. The remaining three days of the preliminary period show values of $11.71 \mathrm{gm} ., 10.88 \mathrm{gm}$. and 11.48 gm. respectively for the urinary chlorid concentration. On the first day of the period of copious water-drinking the excretion of chlorids was increased to $15.58 \mathrm{gm}$., an increase of $4.22 \mathrm{gm}$. above the average daily output (11.36 gm.) of the preliminary interval. This indicates an increase of over 37 per cent. in the total chlorid output. The maximum chlorid excretion, however, occurred on the next day, the second of the water period. On this day the excretion aggregated $25.14 \mathrm{gm}$. as against $15.58 \mathrm{gm}$. for the first day of the period ${ }^{7}$ and as compared with a daily average of $11.36 \mathrm{gm}$. for the preliminary period. This increase of over 121 per cent. above the normal output and of over 61 per cent. above the total output for the first day of copious water ingestion is very surprising and far exceeds that recorded in any of our experiments on any other day of copious water ingestion. The third day of the water period shows a total of $15.64 \mathrm{gm}$. of chlorids in the urine, a value closely comparable to

6. We are indebted to Dr. C. N. Sturtevant for specimens of these urines.

7. Heilner (loc. cit.) in one experiment on a fasting dog made a similar observation when he secured an excretion of $0.44 \mathrm{gm}$. of $\mathrm{NaCl}$ on the first day of increased water ingestion and $0.572 \mathrm{gm}$. on the second day. 
the value of $15.58 \mathrm{gm}$. secured on the first day of the water period. During the final period the excretion for the first twenty-four-hour interval fell to $13.63 \mathrm{gm}$. and underwent a still further decrease to 11.21 gm. on the second day. It will be observed that the excretion for this day was very nearly the same as the daily average excretion for the preliminary period, thus indicating that the course of the excretion had returned to the normal.

\section{GENERAL DISCUSSION AND INTERPRETATION}

Let us first consider the data from Experiment II (see Table 2). In this study we have a pronounced increase in the chlorid excretion on the first day of copious water-drinking, with an excretion nearly as great on the second and last day of the water period. With the opening of the final period with its low water ingestion, we observe a return to the conditions which obtained during the preliminary period, when a similar water ration was fed. Such influence as was exerted by the water on the chlorid output was apparently limited to the two days in which it was ingested in large amount. When we consider the data from Experiment III as given in Table 3, we find a situation very similar to that already mentioned under the second experiment. We have the same preliminary period of fairly uniform output followed by a period of copious waterdrinking in which the chlorid output was markedly increased. The data from these two experiments (II and III) differ, however, in that the former showed the maximum output on the first day of increased water ingestion, whereas the maximum in the latter experiment came on the second day of the water period. We have here, then, two experiments on two different subjects and each of these experiments shows a marked increase in the concentration of the urinary chlorids during the period of copious water-drinking with a return to the normal course as soon as the daily ingestion of the large volume of water is discontinued. The pronounced increases in the chlorid output observed during the water periods of Experiments II and III we would interpret as due principally to the stimulation of gastric secretion through the introduction of the large volumes of water into the stomach. The flushing of the tissues and the stimulation of protein catabolism may have been contributing factors. (These points are further discussed later.)

When we turn to the data from Experiment I (Table 1), we find a condition rather different from the conditions existing in the experiments just discussed. Instead of a period of marked increase in the output of chlorids during the interval of copious water-drinking, we find the excretion but slightly increased during this interval. After the period of copious water-drinking is completed, however, and a return is made to the low water ingestion we observe a pronounced increase in the output 
of chlorids. This increase is of such magnitude as to carry the total output for the day over 18 per cent. above the total increased output for the four days of the water period. How are we to explain the rather unusual course of the chlorid excretion observed in this instance following the ingestion of large volumes of water between meals? The small increased output of chlorids observed during the period of time through which the large volume of water was being ingested might be explained from three different standpoints.

In the first place, we may infer that the pronounced flushing of the tissues by means of this increased fluid ingestion might have caused the observed increase in the urinary chlorin concentration. In fact, we might perhaps expect a decidedly more pronounced stimulation in the chlorin excretion than our data indicate when it is remembered that a volume of water 5,900 c.c. in excess of that customarily ingested was introduced into the body of the subject on each day of the water period.

In the second place, the catabolism of protein matter which has been shown to follow the ingestion of large volumes of water ${ }^{1}$ might explain a part of the rise in the chlorid output. However, that the percentage thus accounted for probably was small will be seen from a consideration of the following calculation:

Protein catabolism during water period represented by loss of $0.68 \mathrm{gm}$. of $\mathrm{N}$.

$N$. in fresh muscle $=3.2$ per cent.

Muscular tissue equivalent to $0.68 \mathrm{gm}$. of nitrogen $=21.3 \mathrm{gm}$.

Chlorin in muscle $=0.069$ per cent.+.

Chlorin content of $21.3 \mathrm{gm}$. of muscle $=0.0144 \mathrm{gm}$.

Blood content of fresh muscle $=7$ per cent.

Rlood in $21.3 \mathrm{gm}$. of musele $=1.491 \mathrm{gm}$.

Chlorin in human blood $=0.26$ per cent.

Chlorin content of $1.463 \mathrm{gm}$. human blood $=0.0039 \mathrm{gm}$.

Chlorin content of $21.3 \mathrm{gm}$. of musele and $1.491 \mathrm{gm}$. of blood $=0.0183 \mathrm{gm}$.

Increased output of chlorin during four days of water period $=0.825 \mathrm{gm}$.

Portion of increased chlorin excretion of water period due to protein catabolism $=2.22$ per cent.

If we consider the increased nitrogen excretion of the water period as arising from stimulated protein catabolism, we find that the increased chlorin output for the corresponding period was abont fifty times too large to be accounted for on that basis. We might perhaps be permitted to assume in this connection that the increase in the nitrogen and chlorid concentrations of the urine arose principally from the catabolism of nitrogenous body tissues, the chlorin being excreted in its entirety whereas the greater part of the resulting nitrogen was resynthesized within the organism ${ }^{8}$ in some way, thus permitting the excretion of but a small portion of the total amount which resulted from the catabolic processes.

\$This value, according to some investigators, should be 0.04 per cent.

8. Paton: Jour. Physiol., 1910, xxxix, 485. 
In the third place, we may look on the increased chlorid output in the urine of the water period as due to the fact that the introduction of this large volume of water into the stomach has furnished sufficient stimulation to produce an increased outpouring of gastric juice. This excess hydrochloric acid, we may suppose, appears in the urine as ammonium chlorid, thus raising the chlorid content of that excretion. That water does possess the stimulatory power mentioned above has been shown by Pawlow ${ }^{9}$ and more recently by Foster and Lambert. ${ }^{10}$ These latter investigators furnished very convincing proof of the fact that the entrance of water into the stomach does not dilute the gastric juice as formerly believed but acts as a stimulant and is followed by a more copious outpouring of gastric juice possessing a higher acid concentration. We have recently obtained experimental evidence in corroboration of these findings. ${ }^{11}$ When the combined evidence from these different sources is taken into consideration with the further fact that Walter ${ }^{12}$ has shown that hydrochloric acid fed to dogs is excreted in the urine mainly in the form of ammonium chlorid, we have a very strong foundation for the claim that at least a portion of the increased output of chlorids observed during the water period of our experiment was due directly to the stimulation of the gastric secretion through the agency of the excess water ingested.

It is apparent from the above discussion that rather logical arguments may be deduced for the explanation of the increased output of chlorids following copious water ingestion on the basis of either of three distinct theories. Does the cooperation and coordination of these three factors discussed above bring about the conditions observed to surround the chlorid output or does the efficient force reside in one individual factor? It would be difficult to divorce ourselves entirely from the belief that the flushing of the tissues of a man's body with 5 liters of water does not to some small degree, at any rate, increase the content of urinary chlorids. When we search the records for experimental verification of our belief, however, we fail to find such verification. On the other hand, we have definite and convincing experimental evidence that increased protein catabolism as well as an increased flow of gastric juice accompanies copious water ingestion. ${ }^{\mathbf{1}, 10}$ It is possible, therefore, for the chlorin output to be augmented from these two sources. But which of these two factors are we to consider the more efficient in this regard?

On the basis of mathematical calculation we have shown that a very small part of the increased output of chlorids following copious waterdrinking arose from increased protein catabolism, unless we are to accept

9. Pawlow: The Work of the Digestive Glands, p. 125.

10. Foster and Lambert: Jour. Exper. Med., 1908, x, 820.

11. Wills and Hawk: Unpublished data.

12. Walter: Arch. f. exper. Path., 1877, vii, 148. 
the theory that the major portion of the resulting nitrogen was not excreted in the urine. Therefore with no experimental evidence in favor of the "flushing" hypothesis and with only a small part of the output accounted for on the basis of increased protein catabolism we must logically turn to the stimulated gastric secretion for a solution of the problem. Experimental evidence already mentioned has demonstrated conclusively that the ingestion of large volumes of water is accompanied by the outpouring of an increased volume of gastric juice which possesses a hydrochloric acid concentration higher than normal. We would, therefore, interpret our data as indicating an increased chlorid output brought about through the fact that the unusually large volumes of water ingested have caused a pronounced stimulation of the gastric function. The excess hydrochloric acid thus produced is reabsorbed from the intestine and is mainly excreted in the urine as ammonium chlorid, thus increasing the chlorid concentration of the urine. It is entirely possible that all three factors previously mentioned (flushing of tissues, catabolism of protein matter, increased flow of gastric juice) are contributing forces in increasing the chlorin output, but we believe the major part of the increase is due to the increased flow of gastric juice.

None of the theories just advanced as explanatory of the increased output of chlorids observed during the period of copious water ingestion, however, can well explain the reason for the very pronounced increase in the chlorid excretion on the day following the four-day period of high water intake of Experiment I. We cannot explain this finding on the basis of the tissue-flushing properties of the ingested fluid, inasmuch as the volume of water ingested on this day was only 400 c.c. as compared with an ingestion of 5,900 c.c. for each day of the water period. That there was no "latent period," causing the water ingested on the last day of the water period to be mainly retained within the tissues and organs of the body until the next day and thos by means of its flushing activities cause a pronounced increase in the chlorid output for the first day of the final period is also apparent. This is clearly shown by the observation that on an ingestion of 2,100 c.c. of milk and 400 c.c. of water the total urine volume was only 1,025 c.c., or 41 per cent. of the fluid ingested.

The hypothesis that the increased chlorid output was due to protein catabolism is not in keeping with the facts shown by the analytic data, as the day in question, although showing the maximum chlorin output, was somewhat below normal in its nitrogen excretion. Likewise, it will be found that the stimulatory power of the water, in causing an additional outpouring of gastric juice and thus directly increasing the chlorid concentration of the urine, is also incompetent to explain the large percentage increase in the chlorid output for the first day of the final period. 
In order to accept this factor as explanatory of the observed phenomenon, we must admit that a small volume of water has a more pronounced stimulatory action than a large volume of the fluid. Evidence adduced by Pawlow ${ }^{9}$ and by Foster and Lambert ${ }^{10}$ as well as the data from certain experiments made by one of us in the laboratories of the University of Illinois, ${ }^{13}$ indicates very clearly that such a theory is untenable. How, then, are we to explain this increased excretion of chlorid, which is nearly 13 per cent. above that observed during the normal period and about 9 per cent. above the average daily output for the water period? We would suggest the following explanation: the absorption of the large volume of water from the intestine causes a temporary increase in the volume of blood within the vessels of the circulatory system. In order to maintain this augmented volume at the proper chlorid concentration, the excess chlorin resulting from the stimulation of gastric secretion is utilized and in addition chlorids are withdrawn from the body tissues, either by a process of flushing or as a result of the protein catabolism induced by the copious water ingestion. Finally, however, the excess fluid is withdrawn from the blood and eliminated from the body by way of the urine. The withdrawal of this water causes a gradual increase in the chlorin content of the blood, and therefore, in order to reduce this content to the normal concentration, the withdrawal of the excess water is followed by the passage of some of this excess chlorin into the urine.

On the basis of the above theory there would be a small increased output of chlorids on each day of increased water ingestion and a more pronounced outpouring of chlorids on the first day following the period of water ingestion. The large increase in the chlorin concentration of the urine of this day would be due to the fact that the large volume of water is suddenly eliminated from the diet at a time when the bloodvessels contain an excessive volume of blood whose chlorin concentration has been maintained through the utilization of gastric juice chlorin and the abstraction of tissue chlorids. This excess water is eliminated from the blood and no excess water is present to be absorbed from the intestine and thus maintain the conditions which were in force during the water period. In this dilemma the entire blood-stream transfers its burden of excess chlorids to the urine and the normal equilibrium is restored. The rate of this process would be regulated somewhat by the office exerted by the body tissues in furnishing water to the blood in order to properly dilute the concentrated menstruum. This factor would tend to delay, to some degree, the passage of the blood chlorids into the urine.

The abnormally low excretion of chlorids on the second day of the final period is apparently simple of explanation. Throughout the water period, as well as during the first day of the final period, the body has

13. Wills and Hawk: Unpublished data. 
been excreting undue quantities of chlorids in the urine. This excess chlorin has been furnished by the gastric juice and the body tissues. The thing of prime importance now for the organism is to restore to the tissues the chlorids they yielded to the blood-stream when needed to maintain the normal concentration of that medium. The blood is now possessed of its normal chlorin content whereas the tissues are subnormal in this respect. On the ingestion of the usual daily quota of chlorin, therefore, the tissues abstract sufficient of the element to replace that previously lost. On this theory the excretion of only $9.8 \mathrm{gm}$. of chlorids, expressed as sodium chlorid, on the second day of the final period, is easy of explanation. The demands of the tissues are probably not satisfied in a single twenty-four-hour period, however, but in a comparatively short time they regain their normal chlorin content.

When we examine the chlorin output for the different three and onehalf hour periods of the rarious days an interesting feature is noted. On every day of the water period the maximum excretion of chlorids occurred during the second period of the day, i. e., from 11:30 a. m. to 3 p. m. The data from the days of the preliminary and final periods in which the urine was collected in these short periods do not show any such uniformity. In the preliminary period the maximum output was excreted during the third three and one-half-hour period, i. e., from 3 p. m. to $6: 30 \mathrm{p}$. m., whereas in the final period the urine passed. between $6: 30 \mathrm{p}$. m. and $10 \mathrm{p}$. m. showed the highest chlorid concentration. If we now examine the data for the urine flow during the water period we shall observe that the periods of maximum chlorid excretion were also periods of maximum urine flow. This fact apparently lends some emphasis to the theory that the excess output of chlorids noted during the water period originated through the flushing of the tissues. When we consider, howerer, the further fact that between 11:30 a. m. and $3 \mathrm{p}$. m. occurred the mid-day meal we are confronted with the possibility that the chlorin excess may have been due to the water acting as a stimulant to the gastric secretion. But why should this period between $11: 30 \mathrm{a} . \mathrm{m}$. and $3 \mathrm{p}$. m. show a larger output of chlorids and of urine than the period from $3 \mathrm{p}$. m. to $6: 30 \mathrm{p}$. m. or the one from 8 a. m. to 11:30 a. m., inasmuch as each of these periods also includes one of the three uniform meals?

Let us consider the factors tending to influence the urine flow during the different three and one-half-hour periods. We notice, in the first place, that the opening period of the day, i. e., from 8 a. $\mathrm{m}$. to $11: 30$ a. m., exhibits the lowest urine volume on every day of the experiment. This low volume no doubt results from the fact that a period of nine and one-half hours $(10 \mathrm{p} . \mathrm{m}$. to $7: 30 \mathrm{a}$. m.) has elapsed since the last water was ingested. Hence the tissues absorb and retain a certain per- 
centage of the rater ingested during this first period. For this reason the volume of urine is low. The next period, i. e., from 11:30 a. m. to 3 p. m., opens therefore with the tissues possessing a relatively high water content. Under these conditions the major portion of the ingested water is ejected thus causing a high urine volume. The second meal of the day comes in the early part of this period $(12: 30 \mathrm{p} . \mathrm{m}$.$) and the$ urine flow for this three and one-half hour period is therefore augmented by a large part of the extra fluid ingested at that time. The third period of the day, i. e., from 3 p. m. to $6: 30$ p. m., also opens with the tissues well supplied with water but the conditions in this case differ from those in force during the previous period in the relative position of the meal within the period. In this case the meal comes near the close of the period and therefore the excess fluid is not eliminated quickly enough to permit any considerable portion of it being included in the period urine volume. From the above discussion it must be apparent that we might logically expect the maximum urine flow during the interval from $11: 30$ a. m. to $3 \mathrm{p}$. m. on each day of copious water ingestion.

An argument similar to the above may be advanced to account for the maximum chlorin output during the second period of the day, i. e., from 11:30 a. m. to $3 \mathrm{p}$. m. One-third of the chlorid ingested in the food during the day is introduced into the body during the early portion of this period. It enters at a time when the vessels of the circulatory system and the tissues are water laden and are encleavoring to maintain the blood at its normal concentration. Under these circumstances a portion of this ingested chlorin would naturally be utilized in adjusting the osmotic relations between the blood and the body tissnes and the greater part of the excess would be eliminated from the body in the urine.

\section{RELATION BETWEEN THE VOLUMES OF INGESTED AND IXICRETED FLUIDS}

This relation, as found in Experiment I, has been shown in tabular form in Table 4. From an examination of the data recorded in this table it will be seen that the daily ingestion of fluid (water and milk) during the preliminary period was 2,500 c.c., no correction being made for milk solids. On this fluid ingestion there was excreted by the subject on the opening day of the test 900 c.c. of urine, or only 36 per cent. of the fluid rolume ingested. On the next two days of this period the values rose to 53.2 per cent. and 54 per cent. respectively.

With the opening of the water period the relation observed during the preliminary period was considerably altered. For example, on the initial day of this period 84.0 per cent. of the ingested fluid was excreted, the intake aggregating 8,000 c.c. followed by an outgo of 6,720 c.c. On the remaining three days of the period when similar volumes $(8,000$ c.c.) 
TABLE 4.-RELATION BETWEEN THE VOLUMES OF INGESTED AND EXCRETED FLUIDS

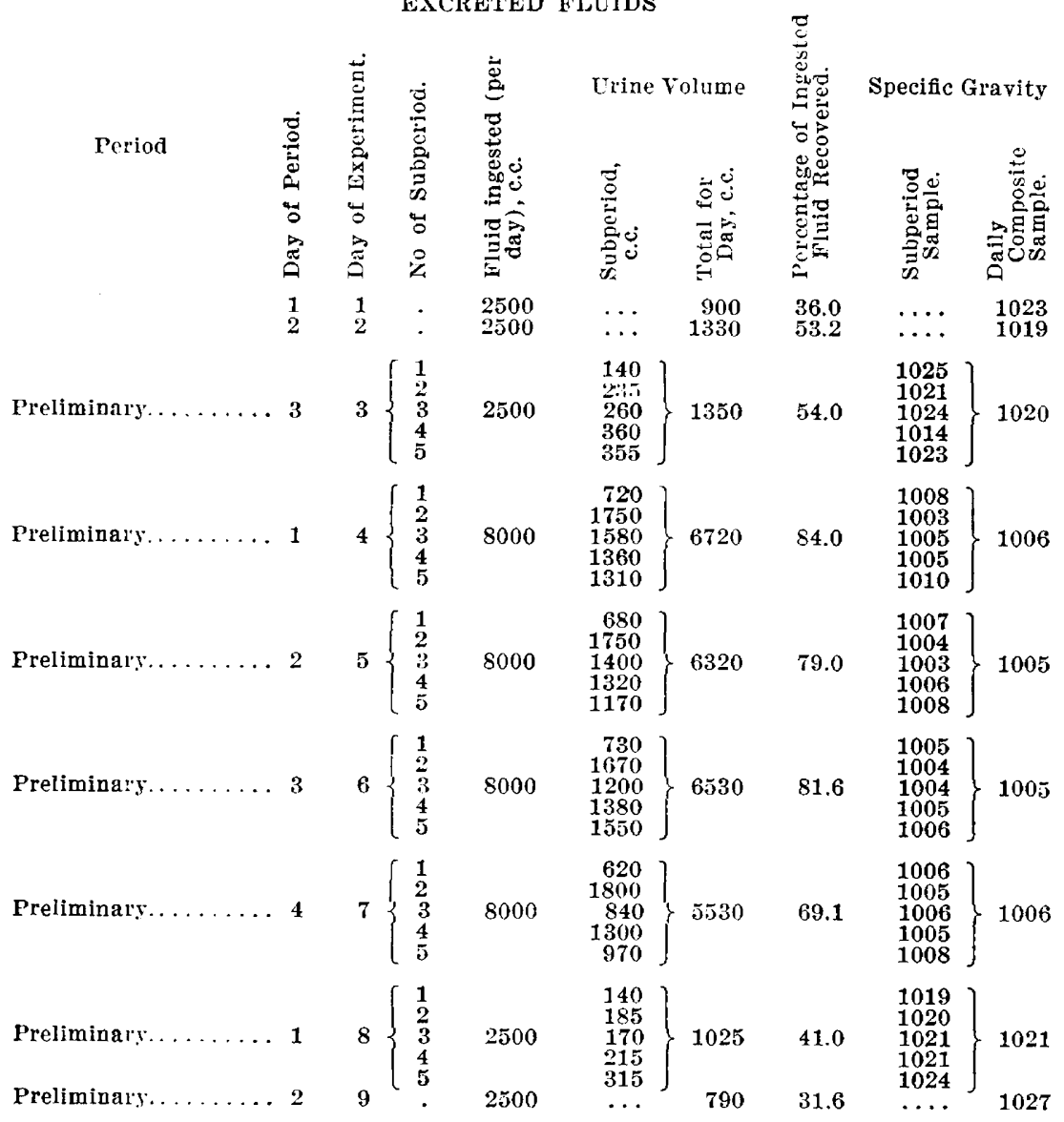

were ingested the urine contained volumes equivalent to 79 per cent., 81.6 per cent. and 69.1 per cent. of that ingested. We thus see that on each day of the water period a higher percentage of the ingested water was excreted than on any day of the preliminary period. The percentage excretion for the final period, when the same volume of fluid was ingested as during the preliminary period, i. e., 2,500 c.c., was 41 per cent. for the first day and 31.6 per cent. for the second day of the period, the last day of the experiment.

From a consideration of all the data on fluid ingestion and excretion it is evident that on the days of low fluid intake a small percentage of the fluid ingested was excreted in the urine. On the other hand, during the water period when large volumes of fluid were being introduced into the organism a higher percentage of the ingested fluid was eliminated in the urine. These data confirm those obtained by one of us (Hawk) in a previous experiment. Certain fasting studies made at the University of 
Illinois ${ }^{13}$ as well as certain experiments reported by Benedict ${ }^{14}$ indicate a similar relation between the volumes of the ingested and excreted fluids.

The specific gravity of the urine specimens ranged between 1019 and 1027 for the preliminary and final periods and between 1005 and 1006 for the water period. The urine was acid in reaction to litmus throughont the experiment.

\section{SUMMARY}

Three experiments are described in which the topic under investigation was the influence of copious water-drinking between meals on the excretion of chlorids. The subjects were young men ranging in age from 22 to 29 years. Each experiment was divided into three periods, a preliminary period during which nitrogen equilibrium was attained through the feeding of a uniform ration of low water content, a water period during which the uniform ration was supplemented by the drinking of large volumes of water between meals, and a final period in which the conditions of the preliminary period were in force.

In two of the experiments there was a pronounced increase in the output of chlorids on the days of added water intake with a return to normal during the final period. This augmented excretion of chlorids is interpreted as indicating that the large volume of water ingested during this period has markedly stimulated the secretion of gastric juice. The excess hydrochloric acid thus passed into the intestine has been reabsorbed and appears, at least in part, in the urine as ammonium chlorid. The main bulk of the increase in the chlorid excretion we believe to have originated in this way. The flushing of the tissues and the stimulation of protein catabolism brought about by the copious water-drinking may have been contributing forces in causing the increased output of chlorids observed.

In one experiment there was a small increase in the chlorid output on each of the days of increased water ingestion followed by a pronounced rise in the output on the first day following the water period. Neither the flushing properties of the water nor its stimulating efficiency as regards protein catabolism or gastric secretion offers a satisfactory explanation for the high chlorid concentration observed on the day following the period of copious water-drinking. It is evident, in the case of this subject, that the water period ended with the vessels of the circulatory system rather fully distended through the excessive water-drinking. The chlorid content of this large volume of blood has been maintained at the normal level partly through the withdrawal of tissue chlorids. As the period of low water ingestion opens the fluid volume within the bloodvessels is quickly decreased to the normal quota, and this withdrawal

13. Howe, Mattie and Hawk: Unpublished.

14. Benedict: Carnegie Publication, No. 77. 
forces the excretion of the corresponding chlorids. This attempt of the body to maintain the blood at the proper chlorid concentration may, therefore, have caused the elimination of a relatively large quantity of chlorids on the day after the copious water drinking between meals had been discontinued.

If we attempt to account for the increased output of chlorids noted during the period of copious water ingestion on the theory that this increase originated through a stimulated catabolism of protein matter within the organism we find it possible to account for only 2 per cent. or less of the increased chlorin output on this basis.

In every instance in which a portion of the urine of each day of the water period was collected in four subperiods three and one-half hours in length (see Table 1) it was observed that the maximum chlorid output and urine volume occurred during the second period of the day, i. e. from 11:30 a. m. to $3 \mathrm{p}$. m. It was also observed that the highest percentage of ingested fluid (84 per cent.) was excreted during the periods of copious water intake. 